Prepared in cooperation with Air Force Civil Engineer Center

\title{
Water-Table Elevation Maps for 2008 and 2016 and Water-Table Elevation Changes in the Aquifer System Underlying Eastern Albuquerque, New Mexico
}

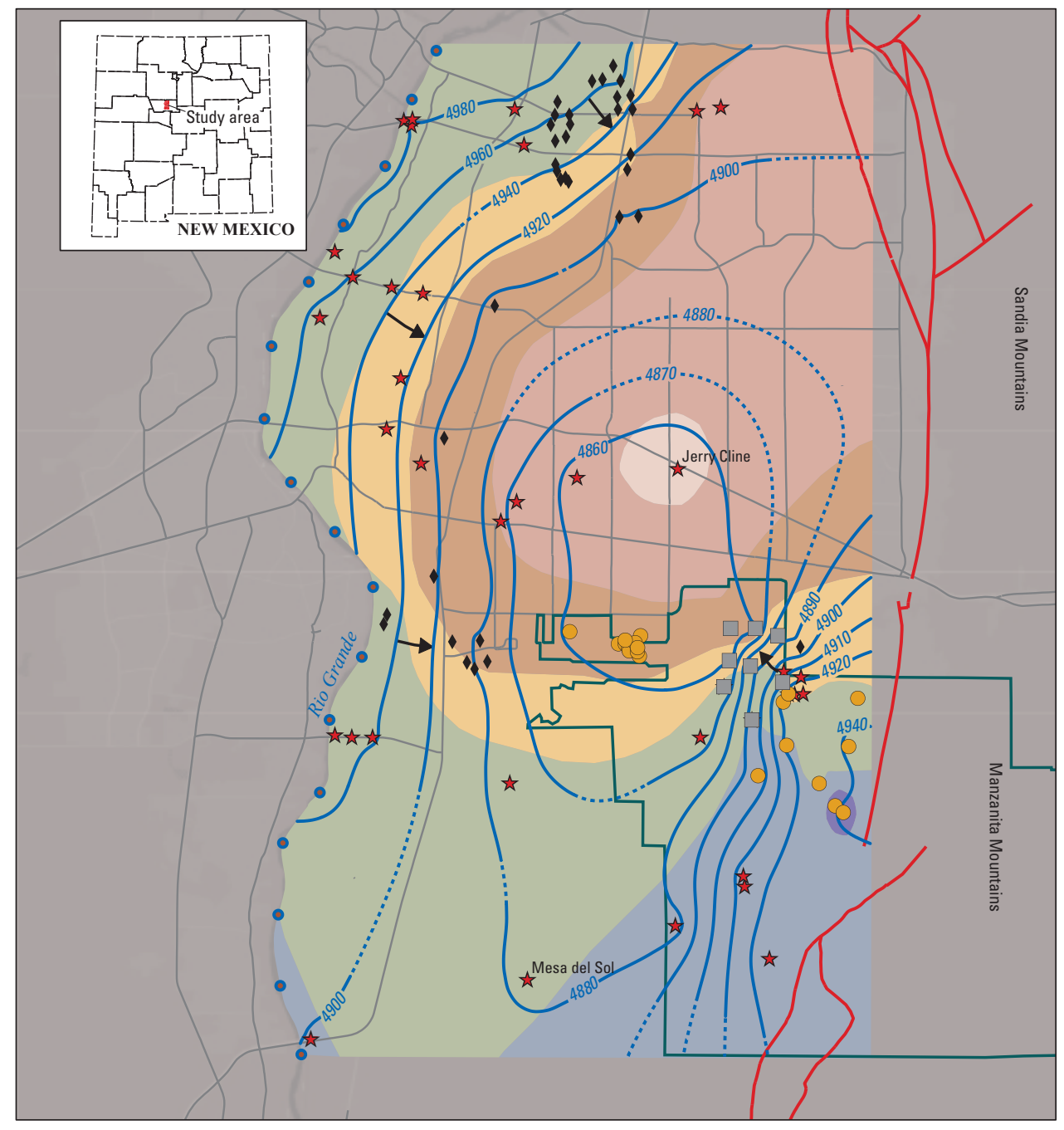

Open-File Report 2020-1036 
Cover. See figure 1. 


\section{Water-Table Elevation Maps for 2008 and 2016 and Water-Table Elevation Changes in the Aquifer System Underlying Eastern Albuquerque, New Mexico}

By Allison K. Flickinger and Aurelia C. Mitchell

Prepared in cooperation with Air Force Civil Engineer Center

Open-File Report 2020-1036 


\title{
U.S. Department of the Interior \\ DAVID BERNHARDT, Secretary
}

\author{
U.S. Geological Survey \\ James F. Reilly II, Director
}

U.S. Geological Survey, Reston, Virginia: 2020

For more information on the USGS - the Federal source for science about the Earth, its natural and living resources, natural hazards, and the environment—visit https://www.usgs.gov or call 1-888-ASK-USGS.

For an overview of USGS information products, including maps, imagery, and publications, visit https://store.usgs.gov/.

Any use of trade, firm, or product names is for descriptive purposes only and does not imply endorsement by the U.S. Government.

Although this information product, for the most part, is in the public domain, it also may contain copyrighted materials as noted in the text. Permission to reproduce copyrighted items must be secured from the copyright owner.

Suggested citation:

Flickinger, A.K., and Mitchell, A.C., 2020, Water-table elevation maps for 2008 and 2016 and water-table elevation changes in the aquifer system underlying eastern Albuquerque, New Mexico: U.S. Geological Survey Open-File Report 2020-1036, 9 p., https://doi.org/10.3133/ofr20201036.

Associated data for this publication:

Flickinger, A.K., and Mitchell, A.C., 2020, Water-tables elevations and other well construction data for 2008 and 2016 in eastern Albuquerque, New Mexico: U.S. Geological Survey data release, https://doi.org/10.5066/P9OHR8Z2.

ISSN 2331-1258 (online) 


\section{Acknowledgments}

The authors would like to acknowledge the Air Force Civil Engineer Center for supporting this research, and the many agencies and organizations that have shared data to make this publication possible, including Sandia National Laboratory, the City of Albuquerque, Kirtland Air Force Base, U.S. Army Corps of Engineers, and AECOM.

The authors also would like to acknowledge the U.S. Geological Survey staff who contributed to this work. 



\section{Contents}

Acknowledgments ……...................................................................................................................

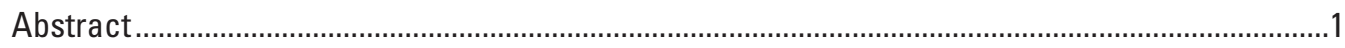

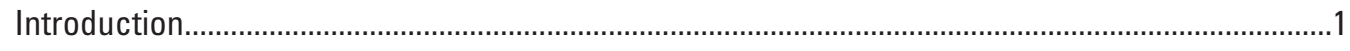

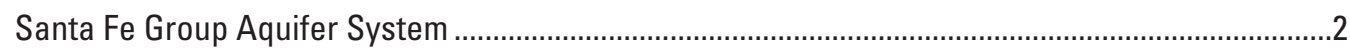

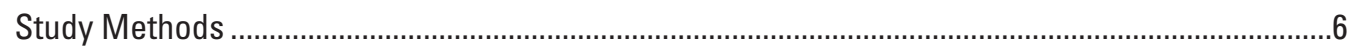

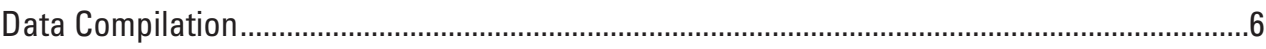

Creation of Maps of Water-Table Elevation and Change ........................................................

Estimated 2008 and 2016 Water-Table Elevation Contours and Change...........................................7

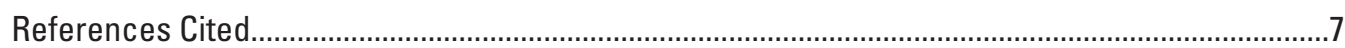

\section{Figures}

1. Map showing estimated groundwater levels in 2008 and changes in water-table elevations from 2008 to 2016, eastern Albuquerque, New Mexico .....................................3

2. Map showing estimated groundwater levels in 2016 and changes in water-table elevations from 2008 to 2016, eastern Albuquerque, New Mexico ....................................

3. Map showing areas of estimated change in water-table elevations from 2008 to 2016 and location of water-level measurement sites (wells) used to delineate the areas of change, eastern Albuquerque, New Mexico

\section{Conversion Factors}

U.S. customary units to International System of Units

\begin{tabular}{llll}
\hline & Multiply & By & To obtain \\
\hline \multicolumn{3}{c}{ Length } \\
\hline foot (ft) & 0.3048 & meter $(\mathrm{m})$ \\
mile (mi) & 1.609 & kilometer $(\mathrm{km})$ \\
\hline
\end{tabular}

\section{Datum}

Vertical coordinate information is referenced to the North American Vertical Datum of 1988 (NAVD 88).

Horizontal coordinate information is referenced to the North American Datum of 1983 (NAD 83).

Elevation, as used in this report, refers to distance above the vertical datum. 


\section{Abbreviations}

ABCWUA Albuquerque Bernalillo County Water Utility Authority

AFCEC Air Force Civil Engineer Center

BFF Bulk Fuels Facility

EDB ethylene dibromide

KAFB Kirtland Air Force Base

lidar light detection and ranging

NWIS National Water Information System

USGS U.S. Geological Survey 


\title{
Water-Table Elevation Maps for 2008 and 2016 and Water-Table Elevation Changes in the Aquifer System Underlying Eastern Albuquerque, New Mexico
}

\author{
By Allison K. Flickinger and Aurelia C. Mitchell
}

\section{Abstract}

The addition of surface water from the San Juan-Chama Drinking Water Project to the Albuquerque water supply and the reduction in per capita water use has led to decreased groundwater withdrawals. This decrease in withdrawals has resulted in rising groundwater levels since 2008 in portions of the aquifer underlying Albuquerque. The wells used to assess the Kirtland Air Force Base Bulk Fuels Facility (KAFB BFF) ethylene dibromide (EDB) groundwater contamination were installed with well screens that crossed the water table in order to monitor and sample groundwater within the EDB plume. While replacement wells have been installed, an understanding of the water-table response to decreases in regional groundwater withdrawals is required to evaluate the monitoring well network. Water-table elevation maps of the aquifer underlying the Albuquerque metropolitan area east of the Rio Grande for 2008 and 2016 and a map of the change in elevations in this 8 -year period provide an improved understanding of the water-table elevations and the changes that are occurring.

The water-table elevation contours for both 2008 and 2016 show that groundwater generally flows from the Rio Grande and from the mountain-front recharge in the southeast toward the center of the study area, a major groundwater pumping center. The water-table elevation increased in most of the study area from 2008 to 2016. The area of greatest increase in the water-table elevation covers most of the northeastern part of the study area, where there has historically been pumping-related drawdown and subsequent groundwater-level rises in the production zone of the Santa Fe Group aquifer system.

\section{Introduction}

The Albuquerque metropolitan area, located in the Middle Rio Grande Basin (Basin) in central New Mexico, has obtained its potable water largely from the Santa Fe Group aquifer system. In December 2008, the Albuquerque Bernalillo County Water Utility Authority (ABCWUA) began diverting surface water from the Rio Grande as part of the San JuanChama Drinking Water Project to supplement municipal water supply. The addition of surface water to the water supply and conservation efforts to reduce per capita water use have led to a 67 percent reduction in groundwater withdrawals between 2008 and 2016 (Galanter and Curry, 2019), resulting in rising groundwater levels throughout the aquifer system since 2008 (Falk and others, 2011; Powell and McKean, 2014; ABCWUA, 2016; Beman and others, 2019; Galanter and Curry, 2019).

Rising groundwater levels indicate recovery of the aquifer system and are a planned result of the ABCWUA's water management strategies (ABCWUA, 2016). Rising groundwater levels, however, could also remobilize or redistribute the fuel-related constituents present in soil, soil vapor, and groundwater at the water table as a consequence of a fuel spill at the Kirtland Air Force Base Bulk Fuels Facility (KAFB BFF). The KAFB BFF ethylene dibromide (EDB) groundwater monitoring well network was installed with well screens open at the water table in order to monitor and sample groundwater within the EDB plume. Many of the well screens have since become submerged (are now below the water table) because of the rising water table (U.S. Army Corps of Engineers, 2017a), and replacement wells have been installed. Understanding the groundwater-level response to decreased regional groundwater pumping is required to evaluate the monitoring well network.

While regional groundwater elevation and groundwaterelevation change maps have been created to understand the changes in the production zone of the Santa Fe Group aquifer system (Bexfield and Anderholm, 2002b; Falk and others, 2011; Powell and McKean, 2014; Galanter and Curry, 2019), no recent maps exist for the water-table zone at a regional scale. The U.S. Geological Survey (USGS), in cooperation with the Air Force Civil Engineer Center (AFCEC), created water-table elevation maps of the Albuquerque metropolitan area east of the Rio Grande for 2008 and 2016, and a third map showing the change between those years to document and analyze the water-table elevations and the changes that have occurred. 


\section{Santa Fe Group Aquifer System}

The Santa Fe Group aquifer system in the Middle Rio Grande Basin consists of the Santa Fe Group and the postSanta Fe Group sediments that were deposited on top of the Santa Fe Group (Bartolino and Cole, 2002). Post-Santa Fe Group sediments are present in the Rio Grande incised valley, along flood plains of Rio Grande tributaries, and at the base of mountain slopes (Hawley and Haase, 1992; Bartolino and Cole, 2002); these sediments can be as thick as 120 feet (ft; Hawley and Haase, 1992). The Santa Fe Group sediments in the Basin range in thickness from 3,000 to $14,000 \mathrm{ft}$ thick; however, much of the lower part of the Santa Fe Group may make a poor aquifer due to its depositional history (Hawley and Haase, 1992; Bartolino and Cole, 2002). The post-Santa Fe Group sediments are not present throughout the Basin (Hawley and Haase, 1992; Bartolino and Cole, 2002), and depending on the depth to water, both Santa Fe Group and post-Santa Fe Group sediments can make up the water-table aquifer. The water table is highest near sources of inflow, such as leakage from the Rio Grande and recharge along the eastern mountain front, and lower near areas of withdrawal, such as centers of groundwater pumping in the central area of eastern Albuquerque (Bexfield and others, 2012). Subsurface flow enters the Basin from the north, and groundwater east of the Rio Grande in Albuquerque flowed from north to south-southwest prior to extensive groundwater pumping (Bexfield and Anderholm, 2000). Only about the upper 2,000 $\mathrm{ft}$ of the aquifer system is used for groundwater withdrawals (Bartolino and Cole, 2002). ABCWUA production wells are typically screened (open to the aquifer) over a part of the Santa Fe Group aquifer system, hereafter called the production zone, which consists of the interval from within about $200 \mathrm{ft}$ above the water table to $900 \mathrm{ft}$ or more below the water table (Bexfield and Anderholm 2002b; Powell and McKean, 2014).

The Santa Fe Group aquifer system in the study area is generally considered to be unconfined, but the interbedded fine-grained layers of the Santa Fe Group create semiconfined conditions at depth (Bexfield and others, 2012). The groundwater elevations measured in wells screened at or near the water table have been found to differ by $25 \mathrm{ft}$ or more from the groundwater elevations measured in wells screened in deeper, semi-confined zones in the aquifer (Bexfield and Anderholm, 2002a). As groundwater levels in the Albuquerque area rise, some nested monitoring wells (two or more casings installed within the same borehole and screened at different depths) show a consistent trend of groundwater-level recovery for shallow, middle, and deep piezometers (Jerry Cline nest, figs. $1,2,3$ ), while other nested monitoring wells show a relatively large recovery in the deepest well screened within the production zone, and a noticeable, yet smaller, rise in water levels in the shallow and middle piezometers (Mesa del Sol nest, figs. 1, 2, 3; Beman and others, 2019). 
$45^{\prime}$

$106^{\circ} 40^{\prime}$

$106^{\circ} 35^{\prime}$

$30^{\prime}$

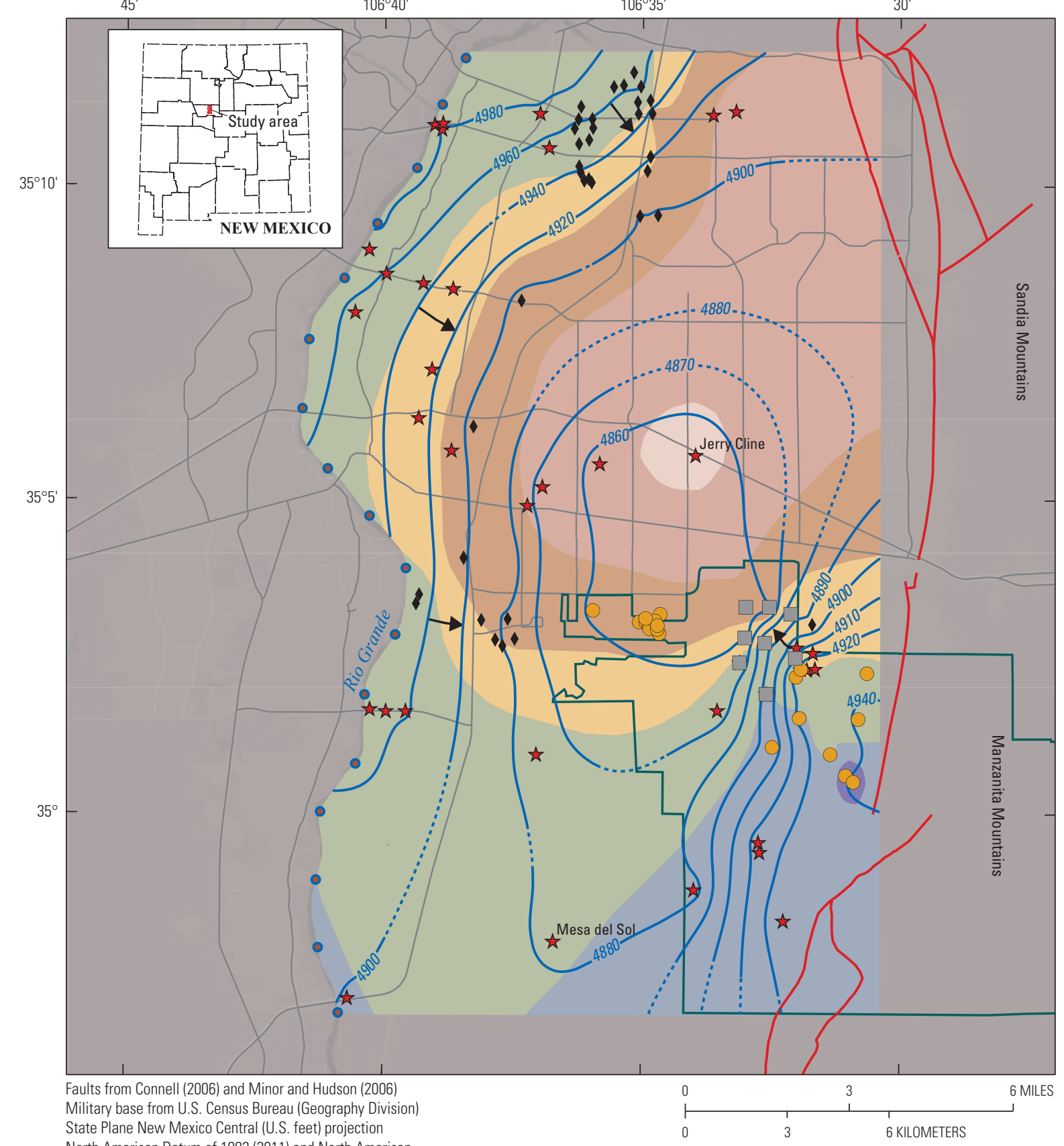

North American Datum of 1983 (2011) and North American

Vertical Datum of 1988

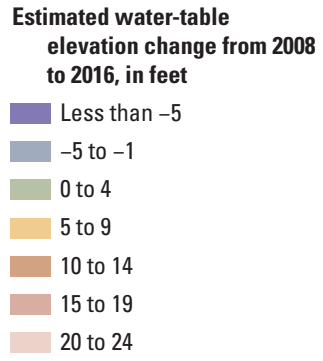

\begin{abstract}
-4880 - Shows the elevation at which water levels would have stood in tightly cased wells. Dashed where approximately located. Contour interval, in feet, is variable. Datum is North American Vertical

Datum of 1988
\end{abstract}

$\rightarrow$ Approximate direction of groundwater flow

\section{EXPLANATION}

— Major faults, concealed and exposed, as identified by Connell (2006), Minor and Hudson (2006)

Kirtland Air Force Base (U.S. Census Bureau, 2015)

- Lidar point along Rio Grande
Wells used to construct 2008 watertable elevation contours

\U.S. Geological Survey (National Water Information System [NWIS], 2019)

- City of Albuquerque (Ken Ziegler, City of Albuquerque, written commun., 2019)

Kirtland Air Force Base (Kirtland Air Force Base, 2017; U.S. Army Corps of Engineers, 2018)

Sandia National Laboratory (J.R. Copland, Sandia National Laboratory, written commun., 2018)

Figure 1. Estimated groundwater levels in 2008 and changes in water-table elevations from 2008 to 2016, eastern Albuquerque, New Mexico. 
$45^{\prime}$

$106^{\circ} 40^{\prime}$ $106^{\circ} 35^{\prime}$ $30^{\prime}$

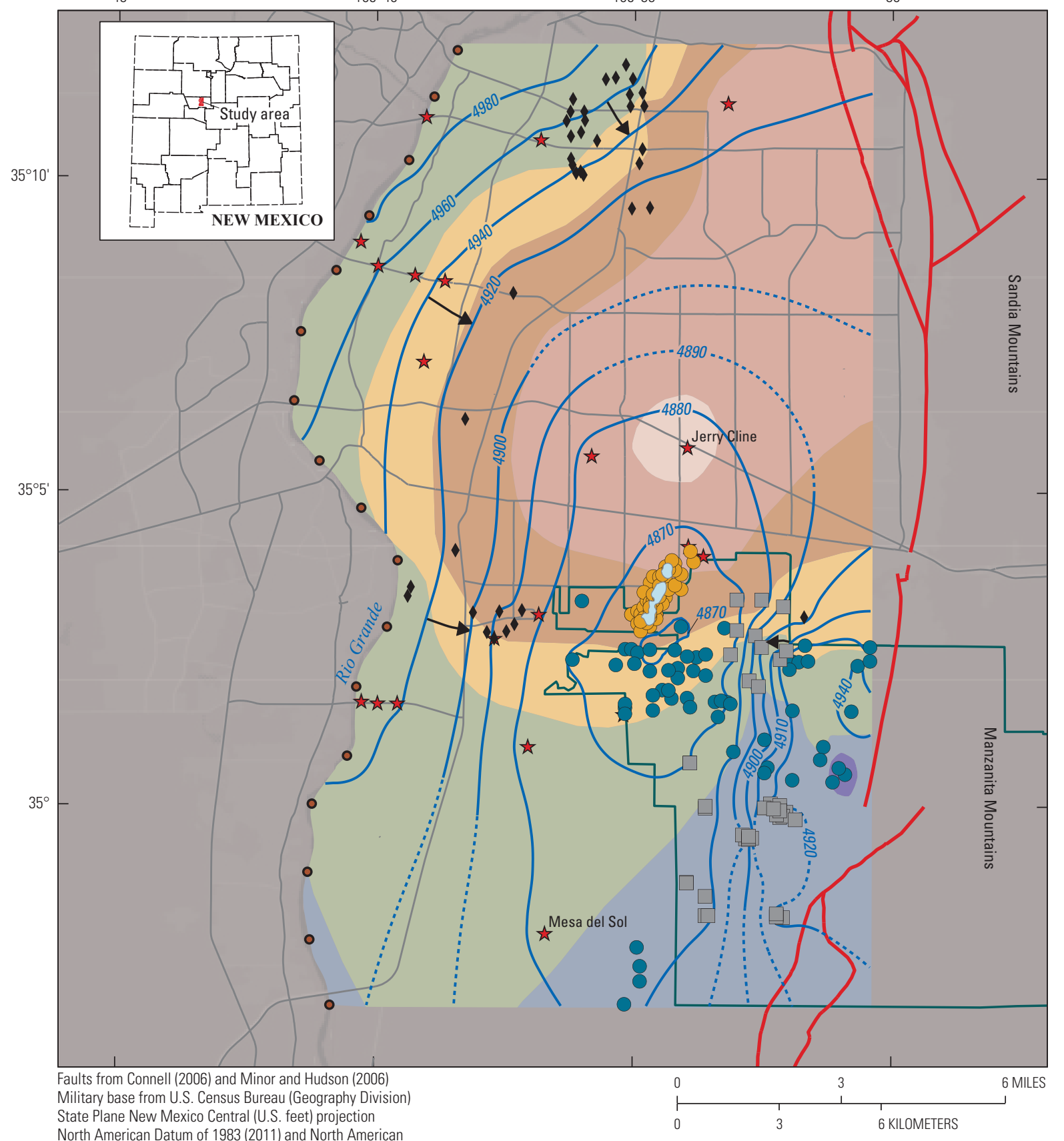

Vertical Datum of 1988

Estimated water-table elevation change from 2008 to 2016, in feet

Less than -5

-5 to -1

0 to 4

5 to 9

10 to 14

15 to 19

20 to 24
Ethylene dibromide (EDB) plume, 2016 October-December extent (U.S. Army Corps of Engineers, 2017b)

-4880 - 2016 water-table elevation contourShows the elevation at which water levels would have stood in tightly cased wells. Dashed where approximately located. Contour interval, in feet, is variable. Datum is North American Vertical Datum of 1988

\section{EXPLANATION}

— Major faults, concealed and exposed, as identified by Connell (2006), Minor and Hudson (2006)

Kirtland Air Force Base (U.S. Census Bureau, 2015)

$\rightarrow$ Approximate direction of groundwater flow

- Lidar points along Rio Grande
Wells used to construct 2016 watertable elevation contours

\ U.S. Geological Survey (National Water Information System [NWIS], 2019)

- City of Albuquerque (Ken Ziegler, City of Albuquerque, written commun., 2019

Kirtland Air Force Base (Kirtland Air Force Base, 2017; U.S. Army Corps of Engineers, 2018)

$\square$ Sandia National Laboratory (Copland, 2017)

- AECOM (Richard Wells, AECOM, written commun., 2018)

Figure 2. Estimated groundwater levels in 2016 and changes in water-table elevations from 2008 to 2016, eastern Albuquerque, New Mexico. 
$106^{\circ} 40^{\prime}$

$106^{\circ} 35^{\prime}$

$30^{\prime}$

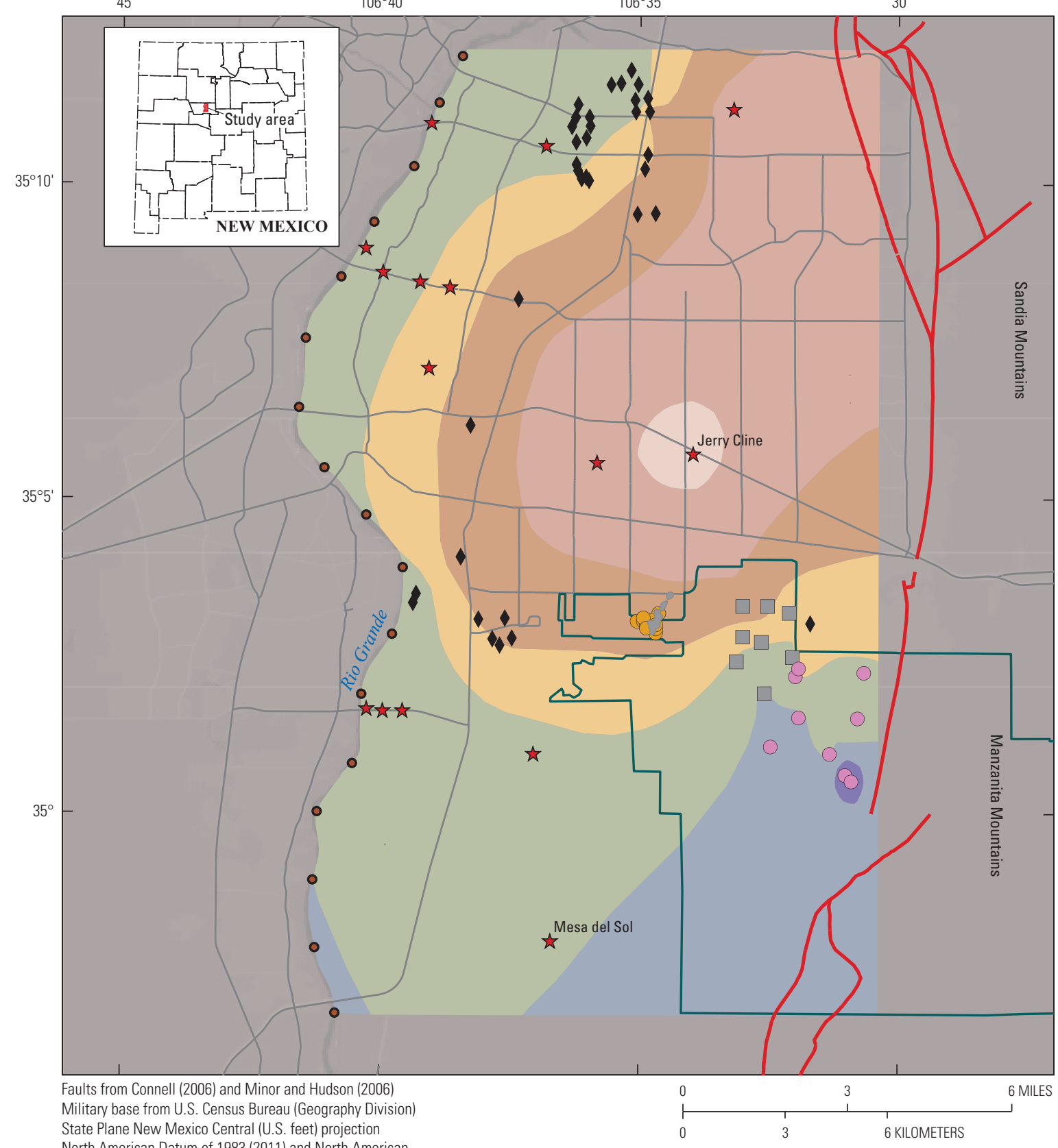

North American Datum of 1983 (2011) and North American Vertical Datum of 1988

\section{EXPLANATION}

Estimated water-table

elevation change from 2008

to 2016, in feet

Less than -5

-5 to -1

0 to 4

5 to 9

10 to 14

15 to 19

20 to 24
Wells used to construct water-table elevation change from 2008 to 2016 $\star$ U.S. Geological Survey (National Water Information System [NWIS], 2019)

- City of Albuquerque (Ken Ziegler, City of Albuquerque, written commun., 2019)

Kirtland Air Force Base (Kirtland Air Force Base, 2017; U.S. Army Corps of Engineers, 2018)
Kirtland Air Force Base (KAFB, 2017; USACE, 2018) and AECOM (Richard Wells, AECOM, written commun., 2017)

Sandia National Laboratory (Copland, 2017; J.R. Copland, Sandia National Laboratory, written commun., 2018) by Connell (200), and Hudson (2006)

\section{Kirtland Air Force Base} (U.S. Census Bureau, 2015)

- Lidar points along Rio Grande

Figure 3. Areas of estimated change in water-table elevations from 2008 to 2016 and location of water-level measurement sites (wells) used to delineate the areas of change, eastern Albuquerque, New Mexico. 


\section{Study Methods}

\section{Data Compilation}

Discrete water-level measurements (depth to water) in wells that are screened near the water table were used to create the water-table elevation contours. The USGS groundwater-level data used are available on the USGS National Water Information System (NWIS) database (https://waterdata.usgs.gov/nwis; USGS, 2019). In addition to NWIS data, water-level and well construction data were compiled from various sources (Copland, 2017; Richard Wells, AECOM, written commun., 2017; KAFB, 2017; U.S. Army Corps of Engineers, 2018; J.R. Copland, Sandia National Laboratory, written commun., 2018; Ken Ziegler, City of Albuquerque, written commun., 2019). All of the data used to create the maps of water-table elevation contours and the zones of change presented in this report are listed in the associated data release (Flickinger and Mitchell, 2020). Depth to water in wells was measured by using either a steel tape or an electric tape. The accuracy of the water-level measurements was reported or assigned for 301 of 321 measurements, and ranges from the nearest hundredth of a foot to the nearest tenth of a foot. Water-table elevation in the well was calculated by subtracting the depth to water measurement from the reference elevation in the North American Vertical Datum of 1988 (NAVD 88). The accuracy of the reference elevations was reported for 55 of 246 sites and ranges from a hundredth of a foot to $5 \mathrm{ft}$.

In order to make the maps in this report more comparable to earlier published maps of groundwater levels in the study area, measurements of water levels made during the winter months (December-March), a period of lower pumping, were used preferentially to construct the maps presented here. For wells used in the construction of these maps for which no winter measurements were available, measurements made during fall and spring months were considered. If multiple winter measurements of water level were available, the measurement showing the shallowest depth to water, presumably the least affected by pumping, was used to represent the elevation of the water table at that well.

The selection of wells completed in the Santa Fe Group aquifer system from which water levels were used to construct the water-table maps was important because of the potential for semi-confined conditions in the deeper aquifer and the potential bias this could have on interpretation of the watertable elevation. Well selection was guided by selected shallow piezometers at USGS nested piezometer sites. The USGS nested piezometers in the Albuquerque area generally have screened intervals near the water table, near the middle of the production zone, and near the bottom of the production zone (Donohoe and Moore, 2003). Eighteen USGS nested piezometers in the study area include a shallow piezometer. The elevations of the screens in the available wells were compared to the elevations of screens of the shallow piezometers to determine which of the wells had water levels that were representative of the water table.

The extent of the water-table zone maps covers the eastern side of Albuquerque, from the Rio Grande to the foothills of the Sandia Mountains. The surface-water level in the Rio Grande was estimated from light detection and ranging (lidar) data collected in 2010 (Caerllion Thomas, Middle Rio Grande Council of Governments, written commun., 2017) and used to represent the water table at the river and act as the western boundary of the map. The lidar data were sampled at 1-mile intervals along the river's edge and included as water-table elevation data points to create the contours. The eastern boundary of the map was constrained by data availability and by faults (Connell, 2006; Minor and Hudson, 2006) that could cause hydraulic discontinuities that could affect groundwater levels. The northern and southern boundaries of the maps are constrained by data availability.

\section{Creation of Maps of Water-Table Elevation and Change}

Water-table elevations determined from depth-to-water measurements and surface-water levels along the Rio Grande were used to create a gridded surface of the 2008 and 2016 water tables by performing a thin-plate spline interpolation (Topo to Raster tool; Esri, Inc., 2019) in ArcPro Release 2 (Esri, Inc., 2017). The gridded surface was then used as input to the Contour tool in ArcPro Release 2 (Esri, Inc., 2017). The resulting contours were manually edited to remove unrealistic features, such as bullseyes, created by the contouring algorithm. Dashed lines were used to represent areas where the contours are inferred because of the sparsity or uncertainty of the data. Data are considered to be sparse when the distance from the contour line to the nearest data-collection site (a well) is farther than two standard deviations of the mean distance between USGS wells. Data are considered to be uncertain if the water-table elevations in closely spaced wells are substantially different or where changes in the shape of the contours are not fully constrained by data.

Seventy-eight sites with selected measurements in both 2008 and 2016 were used to create the areas of water-table elevation change. Change at each site was calculated as the water-table elevation in 2016 minus the elevation in 2008. Zones of water-table elevation change were estimated by interpolating between sites using a thin-plate spline technique (Topo to Raster tool; Esri, Inc., 2019) in ArcPro Release 2 (Esri, Inc., 2017).

Water table contours for 2008 are shown in figure 1, and for 2016 in figure 2. Figure 3 shows the change in water-table elevations from 2008 to 2016. Figures 1-3 are presented as a supplemental online map at https://usgs.maps.arcgis.com/ home/item.html?id=3b038837dfe347daa8691931182788f5. 


\section{Estimated 2008 and 2016 Water-Table Elevation Contours and Change}

The water-table elevation contours for both 2008 (fig. 1) and 2016 (fig. 2) indicate that groundwater generally flows from the Rio Grande into the center of the study area in eastern Albuquerque, a major pumping center (Bexfield and others, 2012). The contours in the southeastern part of the study area indicate that groundwater flows westward from areas of mountain-front recharge at the base of the Manzanita Mountains and then towards the pumping center. The direction of groundwater flow in the southeastern part of the study area, toward the pumping center and the cone of depression formed in response to the withdrawals, is shown by the water-table elevation contours on both the 2008 and 2016 maps of the water table and the production zone (figs. 1 and 2; Falk and others, 2011; Galanter and Curry, 2019) as well as on maps of the production zone for earlier years (Thorn and others, 1993; Bexfield and Anderholm, 2002b).

Only a few wells in the northeastern part of the study area could be considered to be representative of the water table, so no contours of the water table could be drawn with confidence in this area. A network of shallow wells that is spatially extensive would provide a more complete understanding of the water-table response to decreased groundwater pumping in the Albuquerque area. Some differences in the shapes of the 2008 and 2016 water-table elevation contours are attributed to differences in data availability between the two years. For example, there is a "pinched" area on the KAFB just south of the 35th parallel where the 4890- to 4910-ft contour lines for 2016 all appear to converge (fig. 2) that is also seen in previous water-table contour maps of the area (Van Hart, 2003). This "pinched" feature is not present in the 2008 contours (fig. 1), however, possibly because there are no 2008 water-level measurements from the same wells as there were in 2016.

Changes in water-table elevation between 2008 and 2016 varied spatially throughout the study area (fig. 3). Water levels were higher in 2016 in most of the study area, with rises of as much as $22 \mathrm{ft}$. The area of greatest rise in the water-table elevation occurred in the northeastern part of the study area, and although the northeastern part of Albuquerque is included in this area, the change in the water-table elevation in this area is uncertain because of the lack of data, which is indicated by the dashed contour lines (figs. 1 and 2). The area near the Rio Grande and in the southwestern part of the study area had minimal change (less than $5 \mathrm{ft}$ ) in water-table elevation. Water levels, and thus the water-table elevation, decreased in several wells in the southeastern part of the study area (within the KAFB near the Manzanita Mountains). The plume extent in 2016 is shown in fig. 2 (U.S. Army Corps of Engineers, 2017b); the plume extent in 2019 is shown in fig. 3 (KAFB, 2019). The water table has a smaller elevation increase in the area near the EDB plume than in the production zone. The groundwater-level change map of the production zone for 2008 to 2016 indicates there has been an increase of 20-30 $\mathrm{ft}$ near the EDB plume (Ritchie and others, 2019), while the water-table elevation increases in wells near the southwestern end of the EDB plume range from 10 to $14 \mathrm{ft}$ (fig. 3).

\section{References Cited}

Albuquerque Bernalillo County Water Utility Authority (ABCWUA), 2016, Water 2120: Securing our water future: Water Resources Management Strategy, v. I, accessed June 15, 2018, at http://www.abcwua.org/Water_Resources_ Management_Strategy.aspx.

Bartolino, J.R., and Cole, J.C., 2002, Ground-water resources of the Middle Rio Grande Basin: U.S. Geological Survey Circular 1222, 132 p., accessed December 17, 2018, at https://doi.org/10.3133/cir1222.

Beman, J.E., Ritchie, A.B., and Galanter, A.E., 2019, Water-level data for the Albuquerque Basin and adjacent areas, central New Mexico, period of record through September 30, 2017: U.S. Geological Survey Data Series 1113, 39 p., accessed May 13, 2019, at https://doi.org/ $10.3133 /$ ds 1113 .

Bexfield, L.M., and Anderholm, S.K., 2000, Predevelopment water-level map of the Santa Fe Group aquifer system in the Middle Rio Grande Basin between Cochiti Lake and San Acacia, New Mexico: U.S. Geological Survey WaterResources Investigations Report 00-4249, 1 sheet, accessed November 2, 2018, at https://doi.org/10.3133/wri004249.

Bexfield, L.M., and Anderholm, S.K., 2002a, Spatial patterns and temporal variability in water quality from City of Albuquerque drinking-water supply wells and piezometer nests, implications for the ground-water flow system: U.S. Geological Survey Water-Resources Investigations Report 01-4224, 101 p., accessed April 15, 2019, at https://doi.org/ 10.3133/wri014244.

Bexfield, L.M., and Anderholm, S.K., 2002b, Estimated water-level declines in the Santa Fe Group aquifer system in the Albuquerque area, central New Mexico, predevelopment to 2002: U.S. Geological Survey Water-Resources Investigations Report 02-4233, 1 sheet, accessed April 15, 2019, at https://doi.org/10.3133/wri024233.

Bexfield, L.M., Jurgens, B.C., Crilley, D.M., and Christenson, S.C., 2012, Hydrogeology, water chemistry, and transport processes in the zone of contribution of a public-supply well in Albuquerque, New Mexico, 2007-9: U.S. Geological Survey Water-Resources Investigations Report 2011-5182, 114 p., accessed April 15, 2019, at https://doi.org/10.3133/ sir20115182. 
Connell, S.D., 2006, Preliminary geologic map of the Albuquerque-Rio Rancho metropolitan area and vicinity, Bernalillo and Sandoval Counties, New Mexico: Socorro, New Mexico Bureau of Geology and Mineral Resources Open-File Report 496, 2 sheets, scale 1:50,000.

Copland, J.R., 2017, Well construction details, groundwater elevations, and figures for the Tijeras Arroyo groundwater area at Sandia National Laboratories, New Mexico, accessed October 15, 2018, at https://doi.org/10.2172/ 1340634.

Donohoe, L.C., and Moore, S.J., 2003, Description of piezometers installed in the Middle Rio Grande Basin area in and near Albuquerque, New Mexico, 1996-2001: U.S. Geological Survey Open-File Report 2003-290, 63 p., accessed November 2, 2018, at https://doi.org/10.3133/ ofr03290.

Esri, Inc., 2019, ArcGIS Pro: Tool Reference-How Topo to Raster works, accessed May 1, 2019, at https://pro.arcgis.com/en/pro-app/tool-reference/3d-analyst/ how-topo-to-raster-works.htm.

Esri, Inc., 2017, ArcGIS Pro, Version 2.0: Redlands, Calif.

Falk, S.E., Bexfield, L.M., and Anderholm, S.K., 2011, Estimated 2008 groundwater potentiometric surface and predevelopment to 2008 water-level change in the Santa Fe Group aquifer system in the Albuquerque area, central New Mexico: U.S. Geological Survey Scientific Investigations Map 3162, 1 sheet, accessed November 2, 2018, at https://doi.org/10.3133/sim3162.

Flickinger, A.K., and Mitchell, A.C., 2020, Water-tables elevations and other well construction data for 2008 and 2016 in eastern Albuquerque, New Mexico: U.S. Geological Survey data release, https://doi.org/10.5066/P9OHR8Z2.

Galanter, A.E., and Curry, L.T.S., 2019, Estimated 2016 groundwater level and drawdown from predevelopment to 2016 in the Santa Fe Group aquifer system in the Albuquerque area, central New Mexico: U.S. Geological Survey Scientific Investigations Map 3433, 1 sheet, 13-p. pamphlet, accessed May 3, 2019, at https://doi.org/10.3133/ $\operatorname{sim} 3433$.

Hawley, J.W., and Haase, C.S., 1992, Hydrogeologic framework of the northern Albuquerque Basin: Socorro, N. Mex., New Mexico Bureau of Mines and Mineral Resources, Open-File Report 387, 176 p, accessed December 17, 2018, at https://geoinfo.nmt.edu/publications/openfile/downloads/ 300-399/387/ofr_387.pdf.

Kirtland Air Force Base (KAFB), 2017, Quarterly Monitoring Report October-December 2016 and Annual Report for 2016, Bulk Fuels Facility Solid Waste Management Unit ST-106/SS-111: New Mexico, Kirtland Air Force Base.
Kirtland Air Force Base (KAFB), 2019, Quarterly Monitoring Report April-June 2019, Bulk Fuels Facility, Solid Waste Management Unit ST_106/SS-111: New Mexico, Kirtland Air Force Base.

Minor, S.A., and Hudson, M.R., 2006, Regional survey of structural properties and cementation patterns of fault zones in the northern part of the Albuquerque Basin, New Mexico-Implications for ground-water flow: U.S. Geological Survey Professional Paper 1719, 28 p., accessed April 8, 2019, at https://doi.org/10.3133/pp1719.

Powell, R.I., and McKean, S.E., 2014, Estimated 2012 groundwater potentiometric surface and drawdown from predevelopment to 2012 in the Santa Fe Group aquifer system in the Albuquerque metropolitan area, central New Mexico: U.S. Geological Survey Scientific Investigations Map 3301, 1 sheet, accessed November 2, 2018, at https://doi.org/10.3133/sim3301.

Ritchie, A.B., Galanter, A.E., and Curry, L.T.S., 2019, Groundwater-level change for the periods 2002-8, 2008-12, and 2008-16 in the Santa Fe Group aquifer system in the Albuquerque area, central New Mexico: U.S. Geological Survey Scientific Investigations Map 3435, 1 sheet, pamphlet, accessed July 22, 2019, at https://doi.org/10.3133/ $\operatorname{sim} 3435$.

Thorn, C.R., McAda, D.P., and Kernodle, J.M., 1993, Geohydrologic framework and hydrologic conditions in the Albuquerque Basin, central New Mexico: U.S. Geological Survey Water-Resources Investigations Report 93-4149, 106 p., 2 pls., accessed December 17, 2018, at https://doi.org/10.3133/wri934149.

U.S. Army Corps of Engineers, 2017a, RCRA facility investigation report, Bulk Fuels Facility release, solid waste management unit ST-106/SS-111, Kirtland Air Force Base, Albuquerque, New Mexico: Prepared by Sundance Consulting, Inc., January 2017, Albuquerque, New Mexico, variously paged.

U.S. Army Corps of Engineers, 2017b, Quarterly monitoring report October-December 2016 and annual report for 2016, Bulk Fuels Facility, SWMU ST-106 /SS-111: Albuquerque, N. Mex., prepared by EA Engineering, Science, and Technology, Inc., PBC, variously paged.

U.S. Army Corps of Engineers, 2018, Phase I RCRA Facility Investigation Report Bulk Fuels Facility Release, Solid Waste Management Units ST-106/SS-111, Kirtland Air Force Base, Albuquerque, New Mexico: Prepared by Sundance Consulting, Inc., August 2018, Albuquerque, New Mexico, variously paged.

U.S. Census Bureau, 2015, TIGER/Line Shapefile, 2015, U.S., Military Installation National Shapefile, accessed May 1, 2019, at https://catalog.data.gov/dataset/tiger-line-shapefile2015-nation-u-s-military-installation-national-shapefile. 
U.S. Geological Survey (USGS), 2019, USGS water data for the Nation: U.S. Geological Survey National Water Information System database, accessed April 15, 2019, at https://doi.org/10.5066/F7P55KJN.
Van Hart, D., 2003, Geologic investigation: An update of subsurface geology on Kirtland Air Force Base, New Mexico, prepared by Sandia National Laboratories, SAND 2003-1869, accessed December 17, 2018, at https://doi.org/ $10.2172 / 913520$. 
For more information about this publication, contact

Director, New Mexico Water Science Center

U.S. Geological Survey

6700 Edith Blvd. NE

Albuquerque, NM 87113

For additional information, visit

https://www.usgs.gov/centers/nm-water

Publishing support provided by

Lafayette Publishing Service Center 



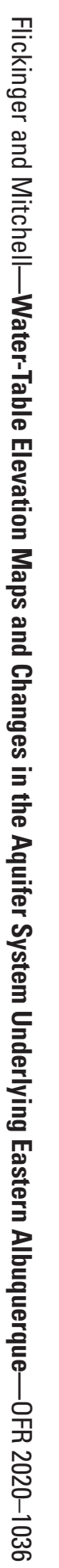

